\title{
Oestrus ovis in sheep: relative third-instar populations, risks of infection and parasitic control
}

\author{
Guillaume TABOURET ${ }^{\mathrm{a}}$, Philippe JACQUIET ${ }^{\mathrm{a}}$, Philip SCHOLL ${ }^{\mathrm{b}}$, \\ Philippe DORCHIES ${ }^{\text {a* }}$
}

\begin{abstract}
a UMR 959, Physiopathologie des Maladies Infectieuses et Parasitaires des Ruminants, École Nationale Vétérinaire, 23 chemin des Capelles, 31076 Toulouse Cedex, France

${ }^{\mathrm{b}}$ US Dept. of Agriculture, Agricultural Research Service, Midwest Livestock Insects Research Unit, University of Nebraska, Lincoln, NE 68583-0938, USA
\end{abstract}

(Received 14 December 2000; accepted 29 June 2001)

\begin{abstract}
Oestrus ovis (L.) (Diptera: Oestridae), the nasal bot fly, has a relatively short free-living life cycle outside of the host, and therefore it is necessary to know when the parasitic period occurs in order to prevent the clinical signs and economic losses caused by this parasite. The length of this parasitic portion of the life cycle is quite variable: a few weeks to several months depending on the season and climatic conditions. Surveys of Oestrus ovis larval populations in sheep show different results on the number of generations according to the local climate. Mean monthly larval profiles of L1 and L3 burdens of sheep from West African Sahelian countries, Mediterranean countries (Morocco, Tunisia and Sicily) and Southwest France were compared. Valuable information on the suspected extension of the fly season is obtained showing the period of infection in each area. This knowledge will be a valuable tool to help in choosing the right treatment at the right period.
\end{abstract}

Oestrus ovis / epidemiology / control

Résumé - Oestrus ovis chez le mouton : population de larves 3, risques d'infestation et contrôle des parasites. Oestrus ovis (L.) (Diptera : Oestridae) a une vie relativement courte dans le milieu extérieur et il est nécessaire de savoir quand la période parasitaire a lieu pour prévenir les signes cliniques et les pertes économiques. La vie parasitaire larvaire dans les cavités nasales a une durée variable de quelques semaines à plusieurs mois selon la saison et les conditions climatiques. Les enquêtes épidémiologiques montrent que les populations de larves chez le mouton et le nombre de générations annuelles sont différentes selon le climat local. Les profils des populations mensuelles moyennes de larves 1 et 3 relevés dans des pays sahéliens, dans des régions méditerranéennes (Maroc, Tunisie et Sicile) ainsi que dans le sud de la France, ont été comparés. Des informations

* Correspondence and reprints

Tel.: (33) 5611938 71; fax: (33) 5611939 44; e-mail: p.dorchies@envt.fr 
intéressantes sur la durée de la période d'activité des mouches ont ainsi été obtenues. Ces éléments pourraient être une aide efficace pour déterminer les périodes de traitement et le médicament le mieux adapté au risque parasitaire présent.

\section{Oestrus ovis / épidémiologie / prévention}

\section{Table of contents}

1. Introduction .526

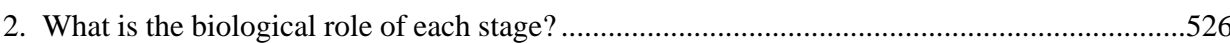

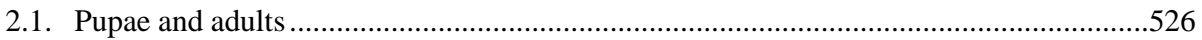

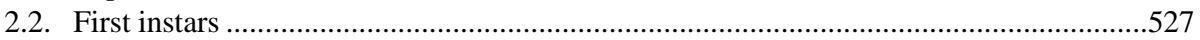

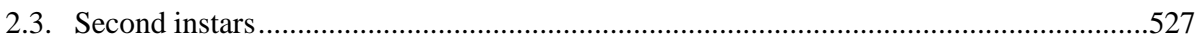

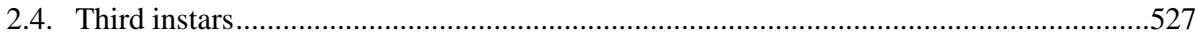

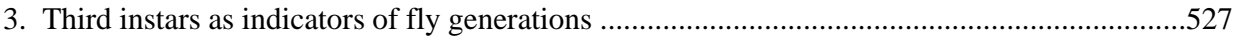

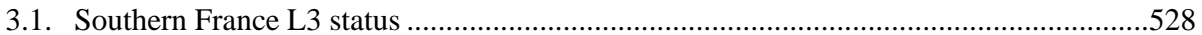

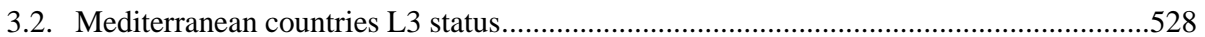

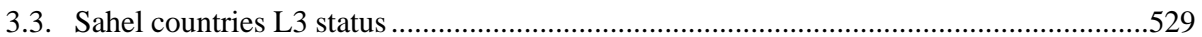

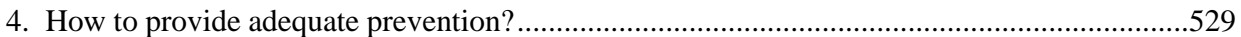

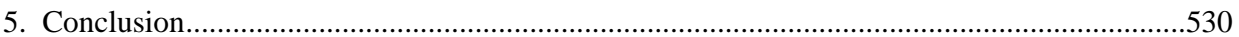

\section{INTRODUCTION}

In order to attempt to control a parasite with a sophisticated life cycle, it is necessary to precisely know the number of generations that occur annually. This knowledge makes the policy of prevention more efficient. Oestrus ovis (L.) (Diptera : Oestridae) has a relatively short free-living life cycle outside of the host, and therefore it is necessary to know when the parasitic period occurs in order to prevent the clinical signs and economic losses caused by this parasite. Some researchers have previously tried to estimate the number of fly generations per year. In Northern Russia [7] and in Egypt [16], there is only one annual generation. This is perhaps due to the very cold temperature in the first area and the dryness in the second. There are two annual generations in India [11], Southern Russia [7], Irak [1], Tchad [17], Kentucky [23] and Tunisia [18]. Finally, in Zaïre [22] and Texas [12] the evolution of the parasite takes place all year round with many generations.

O. ovis adult females larviposit first-instar larvae (L1) into the nostrils of sheep and goats. These early L1 move up through the nasal cavities, moult to L 2 in the sinuses, and finally to the L3 stage which are expelled outside for pupation. The length of this parasitic portion of the life cycle is quite variable from a few weeks to several months depending on the season and climatic conditions.

The aim of this mini-review is to examine and compare the results of surveys performed in areas where climatic conditions are quite different. These results published by several authors will be studied in parallel in order to determine periods of larval evolutions and the risks of infection. This information will allow to discuss the best period of treatment for this parasite if one considers the local conditions.

\section{WHAT IS THE BIOLOGICAL ROLE OF EACH STAGE?}

\subsection{Pupae and adults}

As with other oestrid flies, adults do not feed. They depend on the reserves 
accumulated as larvae to pupate, to eclose, to search for their specific mating site, to mate, to develop the infective larvae inside the females' uterus, and finally to larviposit. Recently, Cepeda-Palacios et al. [10] measured the L3 minimum weight that would assure successful $O$. ovis dissemination, and found that at the lowest weight pupation does not occur.

When they are fully developed, third instars are expelled from the nasal cavities, begin pupation and wait for the right conditions, especially accumulated temperature, for adult eclosion. According to Breev et al. [6], the lowest temperatures for the development of the Oestrus ovis flies are $12.1{ }^{\circ} \mathrm{C}$ for males and $11.5^{\circ} \mathrm{C}$ for females.

Biggs et al. [5] indicated that the duration of pupation was variable. An extended pupation time is an efficient way to avoid the emergence of adults during adverse climatic conditions. This phenomenon may be considered as an external hypobiotic period.

It may be assumed that when the percentages of each of the three instars found in nasal cavities are similar, the development of O. ovis takes place and several generations are produced during that period. Morel [19] and Barré [2] demonstrated the same principle for Amblyomma variegatum: there is no seasonal cycle if the three stages are present all throughout the year as is the case in the Caribbean region. If there is a limited favourable period during the year, some stages delay development in order to wait for the optimal season for breeding.

\subsection{First instars}

As described by Bart and Minar [3], many $\mathrm{L} 1$ are destroyed in the nasal cavities during the hypobiotic period. According to the regional climate, larval development can be arrested either during the cold or during the hot, dry season $[21,25]$. The decrease of the parasite number is partly related to the development of an immune reaction. Nev- ertheless, L1 burdens are the regulators and the insurance of the survival of the parasitic population. It may be assumed that if there is a great number of L3 in the nasal cavities, there will be numerous L1 layed by adults two months later.

\subsection{Second instars}

There is limited information about second instars. These L2 quickly develop in the sinuses of the host and induce a strong cellular reaction in this location with many mast cells and eosinophils. Their development is relative to L3 development and their subsequent elimination to the outside.

\subsection{Third instars}

The L3 larvæ accumulate reserves for pupation [9]. According to Zumpt [26], there is an asynchronous diapause, and few L3 larvae develop simultaneously. The reason is probably spatial: too many larvæ developing at the same time might induce a fatal disease. The rationale of this asynchronous diapause is that the few developing L3 inhibit larvae in the other two previous instars. For this reason, the larval population profile involves many L1, fewer L2 and even fewer L3. When the percentage of L3 increases, mature L3 have to be expelled and cannot stay in the nasal cavities due to their size and to the intense local hypersensitive reaction [20].

\section{THIRD INSTARS AS INDICATORS OF FLY GENERATIONS}

Recently, some papers have given the results of surveys of Oestrus ovis larval populations in sheep showing conflicting values on the number of fly generations each year. These studies were done in the Southwest France [4, 15, 25] in Mediterranean 
countries: Morocco (Dakkak, personal communication), Tunisia [18], Sicily [8] and in the West African Sahelian countries where there is a predominantly dry season from January to June: Senegal [21] and Niger [24]. Monthly L1 and L3 burdens (expressed as a percentage of total parasitic load in infected sheep) were matched (Figs. 1-3). A comparison of the mean monthly larval profiles for each climatic region brings valuable information on the suspected extension of the fly season.

\subsection{Southern France L3 status (Fig. 1)}

According to sheep breeders and veterinarians, the $O$. ovis adult fly season lasts from June to September: at that time they observe the annoyance of sheep due to larvæ laying adult flies. During this period, the development from L1 to L3 lasts an average of 20 days. The percentage of L 3 collected in sinuses of sheep are from 25 to $35 \%$ of the total larval population, close to the L1 percentage. These relative burdens are indicative of rapid larval development and of many emergences of adults from the pupæ [13]. At the beginning of autumn, many L1 accumulate as hypobiotic stages: later there is no living fly until the next spring.
It may be concluded that any treatment given at the end of the fly season (October) will interrupt the evolution of the larvæ and the animals will be free of parasites until the next year that is for 6 or 7 months.

\subsection{Mediterranean countries L3 status (Fig. 2)}

Surveys have been done in Morocco (Dakkak, personal communication), Tunisia [18] and Sicily [8]. Their combined values show uniform percentage of L3, usually about $25 \%$. Except during March, with values about $15 \%$, during the remainder of the year the relative percentages of L3 indicate a year-round development. It appears, due to these favourable climatic conditions, that flies may be active all year round. The risk of infection is present all the year round. This is confirmed by the mean monthly percentages of L1 which are always higher than $35 \%$ and lower than $65 \%$. In these conditions, there is no hypobiotic period usually characterised by the huge predominance of an instar, L1 for example. This epidemiological status indicates that animals have to be treated frequently all the year round. The use of persistent drugs may be useful to have a longer period free of larvæ between two drenches.

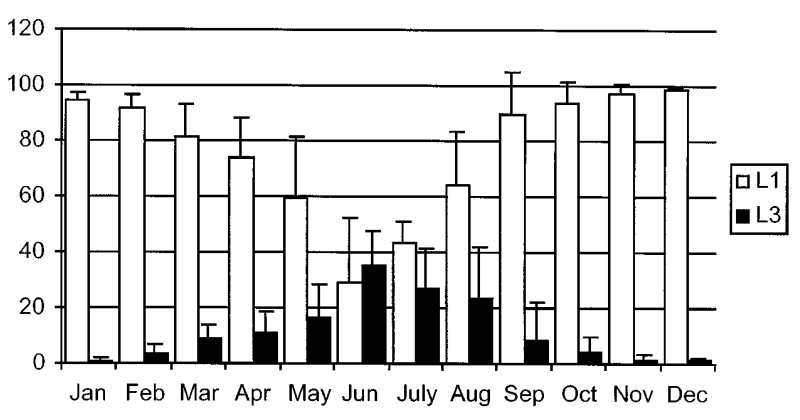

Month
Figure 1. Seasonal evolution L1 and L3 demographic structures in the south west of France. Data from: Yilma and Dorchies [25], Bergeaud et al. [4], Dorchies et al. [15]. 
Figure 2. Seasonal evolution L1 and L3 demographic structures in Mediterranean countries. Data from Morocco (Dakkak, personal communication); Tunisia (Kilani et al. [18]) and Sicily (Caracappa et al. [8]).

Figure 3. Seasonal evolution L1 and L3 demographic structures in Sahelian countries. Data from Senegal (Pangui et al. [21]) and Niger (Tibayrenc et al. [24]).

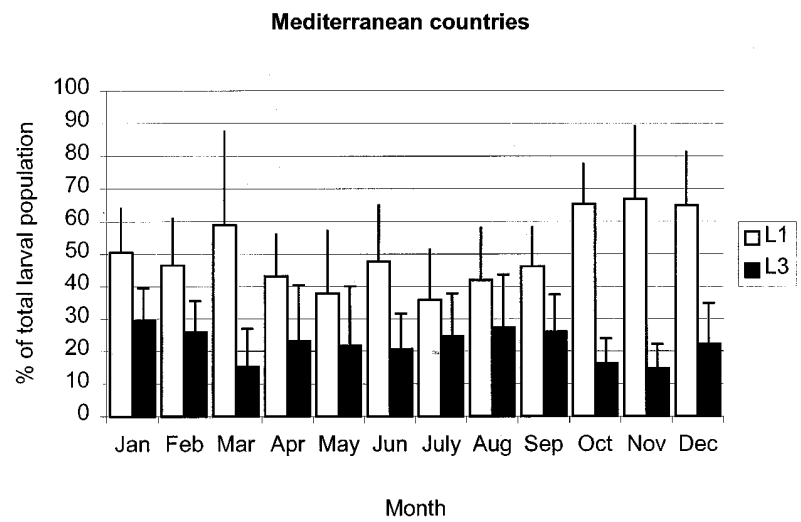

Sahelian countries

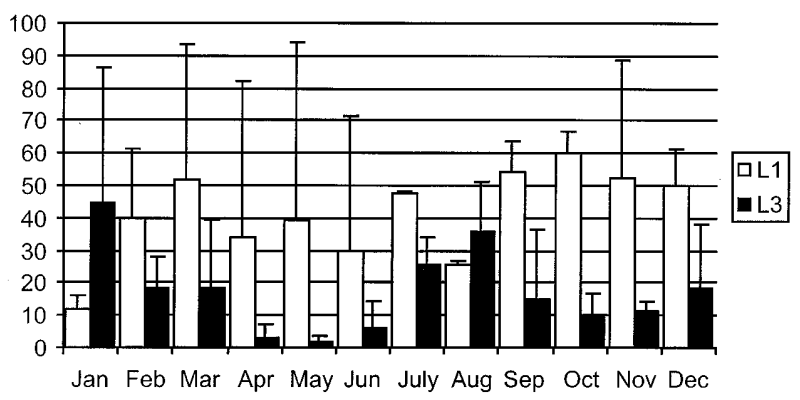

Month

\subsection{Sahel countries L3 status (Fig. 3)}

The results obtained in Senegal [21] and Niger [24] have been matched. In the Sahelian region, the wet season lasts from July to October, the cold dry season from January to March, and the hot dry season from April to June. There are very few L3 during the hot dry season and at the end of the wet season. Most L3 are present during the first part of the wet season and during the cold dry season. These characteristics demonstrate the close association between weather and larval development. There is no true hypobiosis period: the very small number of L3 during April, May and June may be related to a slower development, explain- ing the huge variation of L1 percentages. Finally, as in the Mediterranean areas, the treatments have to be given frequently.

\section{HOW TO PROVIDE ADEQUATE PREVENTION?}

The efficacy of drugs licensed to treat ovine oestrosis is high. Nitroxynil, closantel, ivermectin, doramectin and moxidectin have been shown to be efficient against $O$. ovis larvae. Some drugs such as closantel have a persistent effect on larvæ and may be able to protect animals from reinfection during the fly season [14]. 
The aim of the treatment is twofold: (1) to eliminate or at least to reduce clinical signs and (2) to limit the extension of the endemic zone of the parasite. These goals may be reached by choosing a treatment according to whether or not L3 are present. The three figures show how a global approach may be developed for Oestrus ovis control. If L3 are present, the development of the parasite is taking place: there is further risk of infection by flies and a treatment with a persistent drug is necessary. On the contrary, if there are no L3, i.e. if larvæ are in a hypobiotic phase, it is not necessary to use a persistent product because the risk of reinfection is not as great. This policy would seem to be a valuable tool in helping to choose the right treatment at the right time, and permitting the rotation of classes of drugs and thus delaying or avoiding development of resistance. This hypothesis based on a compilation of results from different areas and under very different climates is confirmed in the field. In France for example, breeders treat their animals during the grazing period with drugs having a persistent efficacy (closantel). The use of non-persistent drug (ivermectin, doramectin or moxidectin per os) to eliminate parasitic burden and avoid long withdrawing period for milk is indicated when ewes returns into sheep fold. At that time there is no risk of reinfection because sheep are inside and adult flies have been killed by cold weather.

Treatments are not frequent in African countries but the hypothesis developed in this mini-review, based on experimental data, could be applied and could be beneficial.

\section{CONCLUSION}

Finally, this paper demonstrates that when L3 are present in nasal cavities there is a parasitic risk in a short term. Therefore it is necessary to treat with a drug having a persistent efficacy to avoid reinfections. On the contrary, if there is no L3 and many hypobiotic L1, drug without residual effect can be administered. Then it appears that the knowledge of parasitic population allows choosing the drug adapted to the local conditions.

\section{REFERENCES}

[1] Abul-Hab J., Seasonal occurrence of sheep bot fly Oestrus ovis, J. Med. Entomol. 7 (1970) 111114.

[2] Barré N., Biologie et écologie de la tique Amblyomma variegatum (Acarina : Ixodina) en Guadeloupe (Antilles Françaises), Thèse de Doctorat, Université de Paris-Sud, Orsay, France, 1989, $268 \mathrm{p}$.

[3] Bart A.G., Minar J., Probability description of regulation on the level of population and individual in the host-parasite system using Oestrus ovis (Diptera: Oestridæ) as an example, Folia Parasitol. (Praha) 39 (1992) 75-83.

[4] Bergeaud J.P., Duranton C., Dorchies Ph., L'œstrose ovine en Aveyron: Résultat d'une enquête sur 1036 têtes à l'abattoir de Rodez, Rev. Méd. Vét. 145 (1994) 863-866.

[5] Biggs H.C., McClain E., Muller G.L., Anthonissen M., Hare K.M., A prediction model for strike in the sheep nasal fly, Oestrus ovis, in Namibia, Prev. Vet. Med. 33 (1998) 267-282.

[6] Breev K.A., Zagretdinov R.G., Minar J., Influence of constant and variable temperature on pupal development of the sheep bot fly (Oestrus ovis L.), Folia parasitol. (Praha) 27 (1980) 359365.

[7] Bukshtynov V.I., Chemotherapy of Oestrus ovis infestation (using dichlorvos), Veterinariya (Mosc.) 9 (1976) 49-50 (in Russian).

[8] Caracappa S., Rilli S., Zanghi P., Di Marco V., Dorchies Ph., Epidemiology of ovine oestrosis (Estrus ovis Linne 1761, Diptera: Oestridæ) in Sicily, Vet. Parasitol. 92 (2000) 233-237.

[9] Cepeda-Palacios R., Avila A., Ramirez-Orduna R., Dorchies Ph., Estimation of the growth patterns of Oestrus ovis L. larvae hosted by goats in Baja California Sur, Mexico, Vet. Parasitol. 86 (1999) 119-126.

[10] Cepeda-Palacios R., Frugère S., Dorchies Ph., Expected effects of reducing Oestrus ovis L. mature larval weight on adult populations, Vet. Parasitol. 90 (2000) 239-246.

[11] Chabrah M.B, Rubrah N.S., Observations on the incidence and biology of Oestrus ovis, Indian Vet. J. 56 (1976) 180-184.

[12] Cobbett N.G., Mitchell W.C., Further observations on the life cycle and incidence of the sheep bot Oestrus ovis in New Mexico and Texas, Am. J. Vet. Res. 2 (1941) 358-366. 
[13] Dorchies Ph., Duranton C., Bergeaud J.P., Alzieu J.P., Chronologie de l'évolution naturelle des larves d'Oestrus ovis (LINNE 1758) chez l'agneau non immunisé, Bull. Soc. Franç. Parasitol. 14 (1996) 20-27.

[14] Dorchies Ph., Alzieu J.P., Cadiergues M.C., Comparative, curative and preventive efficacies of ivermectin and closantel on Oestrus ovis (Linné $1761)$ in naturally infected sheep, Vet. Parasitol. 72 (1997) 179-184.

[15] Dorchies Ph., Bergeaud J.P., Tabouret G., Duranton C., Prevot F., Jacquiet Ph., Prevalence and larval burden of Oestrus ovis (Linné 1761) in sheep and goats in Northern Mediterranean region of France, Vet. Parasitol. 88 (2000) 269-273.

[16] Gaaboub I.A., The distribution and seasonal dynamics of Oestrus ovis L. infesting the nasal cavities and sinuses of sheep in Egypt, Vet. Parasitol. 4 (1978) 79-82.

[17] Graber M., Gruvel J., Étude des agents des myiases des animaux domestiques et sauvages d'Afrique équatoriale, Rev. Elev. Méd. Vét. Pays Trop. 17 (1964) 535-554.

[18] Kilani M., Kacem H.H., Dorchies Ph., Franc M., Observations sur le cycle annuel d'Oestrus ovis en Tunisie, Rev. Méd. Vét. 137 (1986) 451-457.

[19] Morel P.C., Maladies à tiques du bétail en Afrique, in: Précis de parasitologie vétérinaire tropicale, Paris, Ministère de la Coopération et du développement, Institut d'Élevage et de
Médecine Vétérinaire des pays Tropicaux, 1981, pp. 473-717.

[20] Nguyen V.K., Jacquiet Ph., Bergeaud J.P., Duranton C., Prevot F., Dorchies Ph., Réactions cellulaires des muqueuses nasales et sinusales des chèvres et des moutons à l'infestation naturelle par Oestrus ovis Linné 1758 (Diptera : Oestridés), Parasite 6 (1999) 141-149.

[21] Pangui L.J., Dorchies Ph., Belot J., Contribution à l'étude épidémiologique de l'œstrose ovine au Sénégal, Rev. Méd. Vét. 139 (1988) 701-704.

[22] Rodhain J., Matériaux pour l'étude monographique des diptères parasites de l'Afrique II, Révision des Oestrinae du continent Africain Bulletin Scientifique, Franco-Belge 50 (1916) 85-97.

[23] Rogers C.E., Knapp F.W., Bionomic of the sheep bot fly Oestrus ovis, Environ. Entomol. 2 (1973) 11-23.

[24] Tibayrenc R., Roua B., Moumouni R., Garba D., Alassane O., Dorchies Ph., L'oestrose ovine au Niger : enquête de prévalence et traitement par le closantel, Rev. Élev. Méd. Vét. Pays Trop. 52 (1999) 47-53.

[25] Yilma J.M., Dorchies Ph., Epidemiology of Oestrus ovis in southwest France, Vet. Parasitol. 40 (1991) 315-323.

[26] Zumpt P., Myiasis in man and animals in the Old World, Butterworth et Co., London, 1965, $257 \mathrm{p}$. 